\title{
Nanostructured Calcium Phosphates: Preparation and Their Application in Biomedicine
}

\author{
Feng Chen ${ }^{\mathrm{ab}}$, Yingjie Zhu ${ }^{\mathrm{b}^{*}}$, Jin $\mathrm{Wu}^{\mathrm{b}}$, Peng Huang ${ }^{\mathrm{a}}$, Daxiang Cui ${ }^{\mathrm{a}^{*}}$ \\ Shanghai 200240, P. R. China. \\ Shanghai 200050, P. R. China \\ * Corresponding author: E-mail: y.j.zhu@mail.sic.ac.cn (Y. J. Zhu) Fax: +86-21-52413122 \\ E-mail: dxcui@sjtu.edu.cn (D.X.Cui) Fax:+86-21-34206886
}

a Department of Bio-Nano Science and Engineering, Research Institute of Micro/Nano Science and Technology, Shanghai Jiao Tong University,

${ }^{\mathrm{b}}$ State Key Laboratory of High Performance Ceramics and Superfine Microstructure, Shanghai Institute of Ceramics, Chinese Academy of Sciences,

\begin{abstract}
Due to the similar chemical properties to the inorganic component in calcified tissues, synthetic calcium phosphate has been considered as ideal biomaterials with excellent biocompatibility. Nanostructured calcium phosphate materials play an important role in the formation of hard tissues in nature. It is reported that calcium phosphates materials in nano-size can mimic the dimensions of constituent components of calcified tissues. Recently, the synthesis and application of nanostructured calcium phosphate materials have become a very hot field. Lots of methods have been reported to prepare nanostructured calcium phosphate, and various morphologies including nanoparticles, plate-like nanocrystals, nano-needles, whiskers/fibres/ wires, mesoporous, nanotubes, nano-blades, and powders with three-dimensional (3-D) structures have been obtained. More studies of nanostructured calcium phosphates are expected in biomedical area, such as tissue engineering scaffolds, drug/gene delivery systems and multifunctional systems. In this article, the synthesis and application of nanostructured calcium phosphates are reviewed and discussed.
\end{abstract}

Keywords: Calcium Phosphate, Nanostructure, Biomedicine, Hydroxyapatite, Tissue Engineering, Drug Delivery, Gene Delivery.

Citation: F. Chen, et al. Nanostructured Calcium Phosphates: Preparation and Their Application in Biomedicine. Nano Biomed. Eng. 2012, 4(1), 41-49.DOI: 10.5101/nbe.v4i1.p41-49.

\section{Introduction}

Calcium phosphates are abundant in nature, especially in calcified tissue of vertebrate. The inorganic mineral in bone was determined and clarified as carbonated apatite in early $20^{\text {th }}$ century [1]. The constituting building blocks of bone are composites of biological apatite and molecules of collagen $[2,3]$. Calcified tissues, such as bone or dentin contain $\sim 70$ wt. $\%$ apatite and $\sim 20$ wt. $\%$ collagen $[4,5]$. The formation of mineral is the process of in vivo biomineralization, which are built up of mineralized collagen fibrils $[6,7]$. The mineral particles in calcified tissue were studied, and described as plate-like in shape. The thickness of the platelets ranges from 2 to $7 \mathrm{~nm}$, the length from 15 to $200 \mathrm{~nm}$ and the width from 10 to $80 \mathrm{~nm}$ $[2,8]$. These mineral particles are combined with collagen into self-assembled complex hierarchical structure in calcified tissue to achieve a remarkable mechanical performance [9].

Many kinds of materials of calcium phosphates have been prepared. The synthesis and properties of different kinds of calcium phosphates are changed. The standard abbreviations and the chemical formulas of these materials are shown as follows: monocalcium phosphate monohydrate (MCPM, $\left.\mathrm{Ca}\left(\mathrm{H}_{2} \mathrm{PO}_{4}\right)_{2} \bullet \mathrm{H}_{2} \mathrm{O}\right)$, monocalcium phosphate anhydrous (MCPA, $\left.\mathrm{Ca}\left(\mathrm{H}_{2} \mathrm{PO}_{4}\right)_{2}\right)$, dicalcium phosphate dehydrate (DCPD, $\left.\mathrm{CaHPO}_{4} \cdot 2 \mathrm{H}_{2} \mathrm{O}\right)$, dicalcium phosphate anhydrous (DCPA, $\mathrm{CaHPO}_{4}$ ), octacalcium phosphate $\left(\mathrm{OCP}, \mathrm{Ca}_{8}\left(\mathrm{HPO}_{4}\right)_{2}\left(\mathrm{PO}_{4}\right)_{4} \cdot 5 \mathrm{H} 2 \mathrm{O}\right), \alpha$-tricalcium phosphate $\left(\alpha-\mathrm{TCP}, \alpha-\mathrm{Ca}_{3}\left(\mathrm{PO}_{4}\right)_{2}\right), \beta$-tricalcium phosphate ( $\beta$-TCP, $\left.\beta-\mathrm{Ca}_{3}(\mathrm{PO} 4)_{2}\right)$, amorphous calcium phosphate (ACP, $\mathrm{Ca}_{\mathrm{x}} \mathrm{H}_{\mathrm{y}}\left(\mathrm{PO}_{4}\right)_{\mathrm{z}} \cdot \mathrm{nH}_{2} \mathrm{O}, \mathrm{n}=3-4.5,15-20 \% \mathrm{H}_{2} \mathrm{O}$ ), calcium-deficient hydroxyapatite (CDHA, $\mathrm{Ca}_{10-\mathrm{x}}\left(\mathrm{HPO}_{4}\right)$ $\left.{ }_{x}\left(\mathrm{PO}_{4}\right)_{6-\mathrm{x}}(\mathrm{OH})_{2-\mathrm{x}}\right)$, hydroxyapatite $\left(\mathrm{HA}, \mathrm{Ca}_{10}\left(\mathrm{PO}_{4}\right)_{6}(\mathrm{OH})_{2}\right)$, fluorapatite $\left(\mathrm{FA}, \mathrm{Ca}_{10}\left(\mathrm{PO}_{4}\right)_{6} \mathrm{~F}_{2}\right)$ and tetracalcium phosphate (TTCP, $\left.\mathrm{Ca}_{4}\left(\mathrm{PO}_{4}\right)_{2} \mathrm{O}\right)$. The detailed information on calcium phosphates, their synthesis, structure, chemistry, properties and biomedical applications have been comprehensively reviewed recently [10-12]. Due to the high solubility, acidity and basicity, the calcium phosphates materials which have a $\mathrm{Ca} / \mathrm{P}$ molar ratio less than 1 and more than 2 are not suitable for implantation 
into the body [11]. Among the known calcium phosphates compounds, OCP, ACP, $\alpha / \beta-\mathrm{TCP}$ and HA, are significantly useful for biomedical applications. Calcium phosphates are biocompatible, not recognized as foreign materials in the body, and can integrate into living tissue by the same processes active in bone remodeling [13].

Nowadays, the development of nanotechnology has benefited calcium phosphates as biomaterials. It is reported that calcium phosphates materials in nano-size can mimic the dimensions of constituent components of calcified tissues, and be utilized as biomaterials due to their excellent biocompatibility [14]. Lots of method have been reported to prepare nanostructured calcium phosphates, such as co-precipitation, sol-gel synthesis, hydrothermal reaction, mechanical milling, etc., by which calcium phosphate nanoparticles with various shapes and sizes can be obtained [15-21].

Herein, an overview of calcium phosphate materials as biomaterials is given. In this review, the nanoeffects of calcium phosphates materials, synthesis of nanoscale calcium phosphates, as well as applications of nanostructured calcium phosphate in biomedicine have been discussed.

\section{Nano-effects of calcium phosphates materials}

Due to the similar dimensions to the inorganic components of calcified tissues, calcium phosphates materials in nano-size are expected to have better bioactivity compared with conventional materials [22]. The advantages of synthetic calcium phosphates materials in nano-size include higher biocompatibility, good biodegradability in situ, and excellent osteoconductive and osteoinductive capabilities [23, 24].

Calcium phosphates materials in nano-size have higher specific surface area and surface roughness compared to conventional calcium phosphates materials. Therefore, nanosized calcium phosphates materials have stronger interaction with organic materials. For example, nanophase HA appeared to have $11 \%$ more proteins of fetal bovine serum adsorbed per $1 \mathrm{~cm}^{2}$ than conventional HA [25]. HA nanoparticles blended in polyacrylonitrile fibers were found to result in their degree of crystallinity rising by about $5 \%$ [26]. The sinterability of conventional calcium phosphate ceramics made from conventional powders is poor, and the resorption of ceramics is quite different from that of bone mineral [27]. Meanwhile, due to greater specific surface area, calcium phosphates materials in nano-size show improved sinterability and enhanced densification, which may improve fracture toughness, as well as other mechanical properties [24, 28 ]. With high biocompatibility, good surface properties, good sinterability and ability of interaction with organic molecules, synthetic nanostructured calcium phosphates materials have promising applied potential in biomedicine.

\section{Synthesis of nanoscale calcium phosphate}

The bioactivity, biocompatibility, stability and mechanical properties of calcium phosphate materials are usually determined by its composition, structure, morphology and crystallite size [29]. Calcium phosphate with different morphologies including nanoparticles [30, 31], plate-like nanocrystals [32], nano-needles [33], whiskers/fibres/wires [34-36], mesoporous [35], nanotubes [37], nano-blades [38, 39], and powders with three-dimensional (3-D) structures have been prepared [40-42]. The performance of calcium phosphates in applications depends greatly on its morphologies and chemical compositions. To optimize and achieve better performances, controlling the structure and size of calcium phosphate materials is still a hot filed.

\subsection{Calcium phosphate nanoparticles}

Calcium phosphate nanoparticles have been prepared by a variety of techniques such as mechanochemical synthesis, combustion preparation, and wet chemistry techniques [43-45]. The products obtained using method of wet chemistry techniques have controlled size and good dispersing property. The precipitation in solution is an easy method for fabrication of calcium phosphate nanoparticles, and chemical agents such as citric acid, amino acids and ethylenediaminetetraacetic acid (EDTA) have been used to mediate the structure of calcium phosphate nanoparticles [46-48].

Recently, biocompatible block copolymers have been used to control the synthesis of calcium phosphate nanoparticles. For example, calcium phosphate hybrid porous nanospheres have been prepared through a facile PLGA-mPEG/PLA-mPEG assisted route at a relatively low temperature [49-51]. The micelles formed by amphiphilic block copolymer of PLGA-mPEG/ PLA-mPEG act as templates and calcium phosphate is combined with the micelle via the electrostatic interaction between $\mathrm{Ca}^{2+}$ ions and polymer segments.

As a typical solution-based method, the hydrothermal approach has proven to be an effective and convenient process to prepare calcium phosphate nanoparticles. There are many advantages of this method, including easily controllable reaction conditions, relatively large scale and high crystallinity in terms of quantity and quality of the desired products [28]. Zhang et al. [29] reported the synthesis of HA nano- and microstructures using water as a reaction medium through a simple hydrothermal process. Our research group have prepared HA nanorods with relatively uniform sizes and high crystallinity via a hydrothermal strategy [52]. The shape and size of the sample can be adjusted by regulating the reaction conditions. Through hydrothermal treatment, the HA nanorods with larger sizes and higher crystallinity are obtained compared with those prepared at a low temperature.

\subsection{3-D nanostructured calcium phosphate}

Morphologies, 3-D architectures and chemical compositions influence on the performance of calcium 
phosphate materials in their applications. Recently, the fabrication and properties of 3-D architectured calcium phosphate materials have attracted great interests.

It was demonstrated that calcium phosphate hollow nanostructures could be prepared through biomineralization in the presence of polyelectrolyte [54]. Wang et al. synthesized HA microspheres using polyelectrolyte as the morphology directing-agent [55], and poly(styrene sulfonate) (PSS) was used as a modifier with the concentration varied ranging from 0 to $9.6 \mathrm{wt} \%$ during the hydrothermal synthesis of carbonated HA to achieve the controlled morphology and particle size. The presence of PSS drastically changed the growth pattern of HA crystallites. The concentration of PSS was elucidated as an important factor for the formation of HA microspheres of different sizes and hierarchical structures. 3-D architectured calcium phosphate materials were fabricated by the templating method. Schmidt and Tjandra et al. $[56,57]$ coated calcium phosphate on lipsome micelles/block copolymer templates to form nanoshells, and the thickness of shells was controllable by adjusting the addition time of calcium and phosphate salt, and hollow calcium phosphate nanospheres were obtained after calcination. The hard templates were also used to form 3-D architectured calcium phosphate materials. Lin et al. [58] reported that HA nanoparticles, nanowires and hollow nanostructured microspheres were successfully synthesized on a large scale via a facile hydrothermal treatment of similarly structured hard-precursors of $\mathrm{CaCO}_{3}$ nanoparticles, xonotlite nanowires and hollow $\mathrm{CaCO}_{3}$ microspheres in $\mathrm{Na}_{3} \mathrm{PO}_{4}$ solution in the absence of any surfactants, organic solvent or organic templatedirecting reagents, respectively. By using calcium carbonate nano-ellipsoidal particles as hard templates, our group has successfully fabricated HA nanostructured hollow ellipsoidal capsules with a large specific surface area, which exhibited high ibuprofen loading capacity and good releasing property (Fig. 1) [53]. It is a general strategy to delicately control the morphologies of HA materials from simple morphologies to complicated 3D architectures using the hard-template with similar morphologies and architectures.

Beside, surfactants are also usually used as the controlling reagent to prepare 3-D architectured calcium phosphate materials. Cheng and Liu et al. [59, 60] prepared flower-liked HA microspheres using EDTA as the template-directing reagent under hydrothermal treatment and microwave irradiation. The microwaveassisted method has been successfully used for the synthesis of monetite with flowerlike and bundlelike morphologies using $\mathrm{CaCl}_{2} \cdot 2.5 \mathrm{H}_{2} \mathrm{O}$ and $\mathrm{NaH}_{2} \mathrm{PO}_{4}$ in the presence of sodium dodecyl sulfate (SDS) in mixed solvents of water and EG [61]. When the product was immersed in $\mathrm{NaOH}$ solution, the monetite could transform into HA, and the flowerlike structure could be maintained. Block copolymer was also used to control the synthesis of 3-D architectured calcium phosphate materials. Wang et al. [62] reported that flower-like nanostructured
HA hollow spheres assembled with nanosheets with a hierarchical morphology were fabricated via a rapid microwave-assisted hydrothermal route. The presence and concentration of block copolymer poly(lactide)block-poly(ethylene glycol) (PLA-PEG) were important parameters for the formation of the hollow structure.

\subsection{Biomimic calcium phosphate nanomaterials}

The performance of calcium phosphate in biomedical applications depends greatly on its morphologies, architectures and chemical compositions. Therefore, efforts have been done to develop biomimic calcium phosphate nanomaterials. Up to now, the major efforts to develop biomimic HA mainly involved macromolecular and surfactant controlled self-assembling [63-68], and biomineralization [69-73]. Our research group has developed a surfactant-free solvothermal method using $\mathrm{CaCl}_{2}$ and $\mathrm{NaH}_{2} \mathrm{PO}_{4} \cdot \mathrm{H}_{2} \mathrm{O}$ in ternary solvents of water, ethylene glycol (EG) and N,N-dimethylfomamide (DMF) for the preparation of a variety of HA nanowire/nanotube ordered arrays and their fabrics with biomimic structures including HA sheets with brush-like ends, nanotube arrays and their fabrics, nanowire arrays and their fabrics (Fig. 2) [37]. The solvents have obvious effects on the morphology and crystal phase of the product. One advantage of this method is that the hard template and surfactant are not needed, avoiding the procedures and cost for their removal in the product. The as-prepared HA nanowire/nanotube ordered arrays and their fabrics show similarity in structure to the natural hard tissues, and may be potentially useful in biomedical areas.

Lin et al, reported single-crystalline of biomimetic HA porous microspheres with co-substituted essential trace elements $\left(\mathrm{Na}, \mathrm{Mg}, \mathrm{K}, \mathrm{F}, \mathrm{Cl}\right.$ and $\mathrm{CO}_{3}{ }^{2-}$ ) of natural bone synthesized via a facile hydrothermal process at a low temperature [74]. The morphology images of the control sample and synthetic powders CS-HAp1-4 via hydrothermal treatment at $120{ }^{\circ} \mathrm{C}$ for $24 \mathrm{~h}$ are presented in Fig. 3. The biomimetic HA porous microspheres were assembled from the nanosheets with thickness of about $60 \mathrm{~nm}$, widths and lengths of up to $2 \mu \mathrm{m}$. The novel 3-D architectures resulted in favourable drug loading and release property, and the co-substituted essential trace elements enhanced the degradability of the obtained products in comparison with pure HA nano-particles.

Electrospinning has been recognized as an efficient technique for fabricating polymer nanofibers which can be widely used in biomedical areas [75]. Calcium phosphate nanofibers were obtained by electrospinning using solution containing polyvinyl alcohol [76,77]. Our research group reported a simple method for the preparation of HA/PVP composite nanofibers, 3-D fabrics with different shapes and aligned nanofiber arrays by electrospinning (Fig. 4) [78]. Then, the single-phase HA fabrics, tubular morphologies or aligned nanofiber arrays were obtained through thermal treatment of corresponding composite precursors. One of the advantages is that it is facile to obtain HA nanofibrous scaffold with designed 
http://nanobe.org

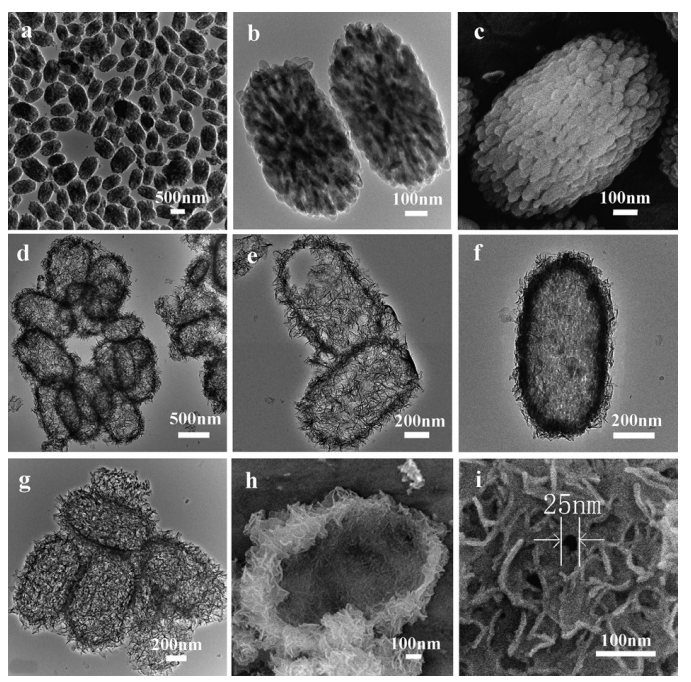

Fig. 1 TEM and SEM micrographs of (a)-(c) $\mathrm{CaCO}_{3}$ cores; (d)-(i) HAp nanostructured hollow ellipsoidal capsules prepared using dilute $\mathrm{H}_{3} \mathrm{PO}_{4}$ : (d) and (e) $\mathrm{H}_{3} \mathrm{PO}_{4}: \mathrm{H}_{2} \mathrm{O}=1: 300$; (f) $\mathrm{H}_{3} \mathrm{PO}_{4}: \mathrm{H}_{2} \mathrm{O}=1: 100$; (g)-(i) $\mathrm{H}_{3} \mathrm{PO}_{4}: \mathrm{H}_{2} \mathrm{O}=1: 100$. Reprinted from Ref. [53].
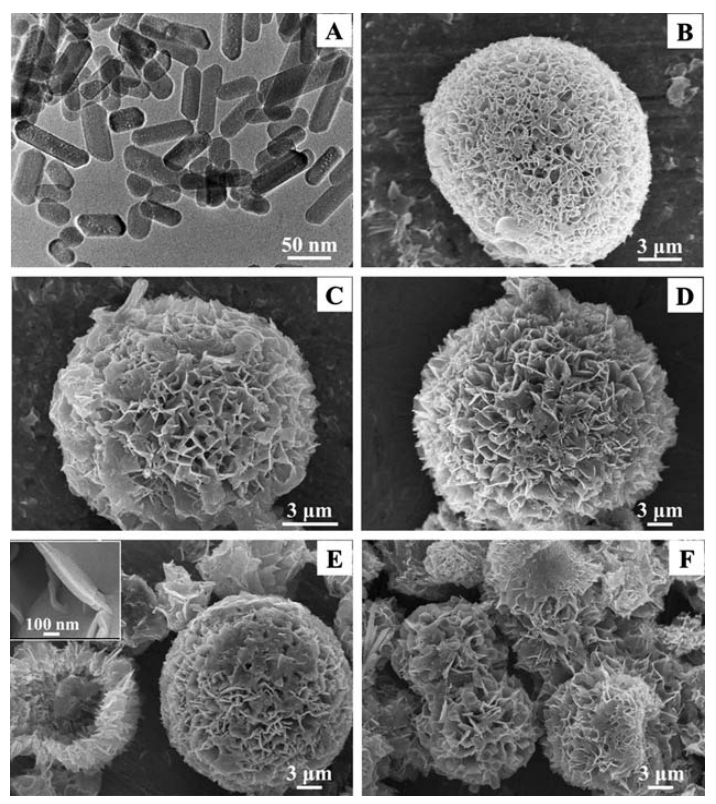

Fig. 3 Morphology images of the control sample (A) and the synthetic CS-HAp1 (B), S-HAp2 (C), CS-HAp3 (D) and CS-HAp4 (E, F) porous microspheres. Reprinted from Ref. [74].

structure. Biomineralization was also used to prepared biomimic calcium phosphate nanostructure combined with the method of electrospinning. Our group reported ACP/ PDLLA composite nanofibers prepared by electrospinning [79]. ACP nanoparticles with diameters ranging from 20 to $80 \mathrm{~nm}$ were synthesized using a simple precipitation method. The hybrid materials showed good ability of biomineralization and cytocompatibility in vitro.

\section{Application of nanostructured calcium phosphate}

\subsection{Hard tissue engineering}

Because of excellent biocompatibility, calcium phosphate based materials have been used in hard tissue repair for decades [80]. The chemical properties of calcium phosphates are similar to the inorganic

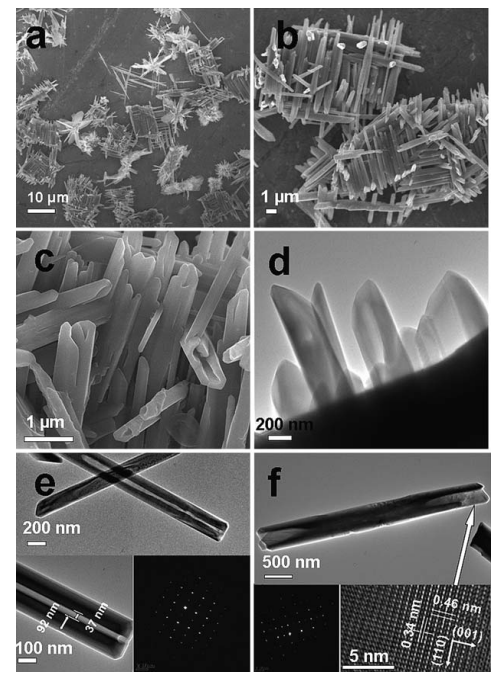

Fig. 2 SEM $(\mathrm{a}-\mathrm{c})$ and TEM $(\mathrm{d}-\mathrm{f})$ micrographs of the HAp sample prepared using $\mathrm{CaCl}_{2}$ and $\mathrm{NaH}_{2} \mathrm{PO}_{4} \cdot \mathrm{H}_{2} \mathrm{O}$ in mixed solvents of $\mathrm{H}_{2} \mathrm{O} / \mathrm{EG}$ / DMF $\left(\mathrm{H}_{2} \mathrm{O} / \mathrm{EG}=1: 1\right)$ by solvothermal treatment at $200{ }^{\circ} \mathrm{C}$ for $24 \mathrm{~h}$. The insets of (e and $\mathrm{f}$ ) are the SAED patterns and HRTEM image. Reprinted from Ref. [37].

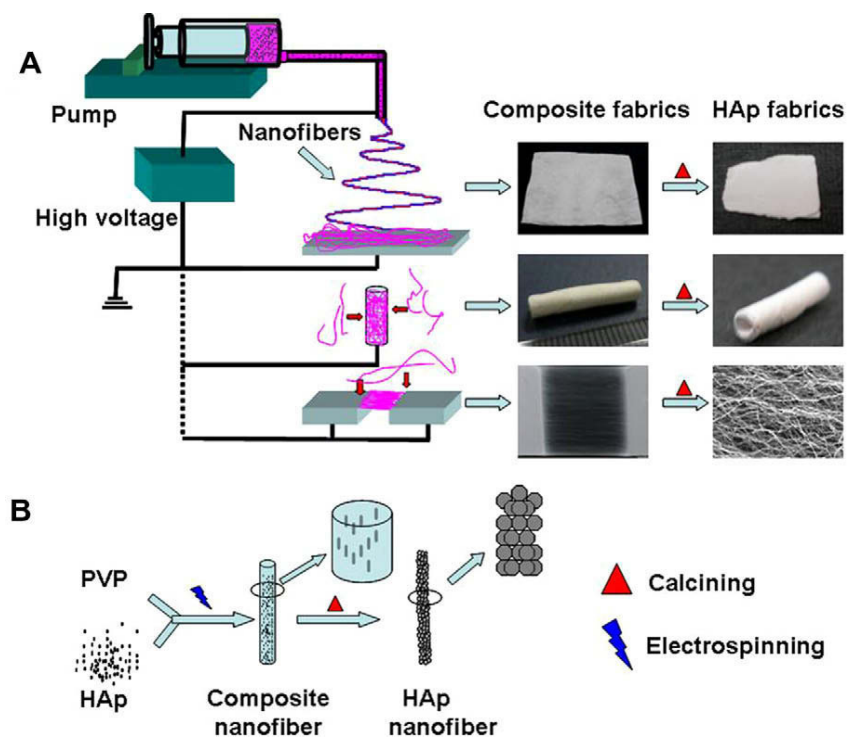

Fig. 4 Scheme of the strategy for fabrication of HAp/PVP composite nanofibers and fabrics (A) and the process of formation of HAp nanofibers (B). Reprinted from Ref. [78].

component in bone tissue. Thus, synthetic calcium phosphates with strong affinity to host hard tissues offer a great advantage in hard tissue repair.

However, the low mechanical properties of traditional calcium phosphate ceramics restrict their use [28]. Recent novel ceramics sintered with nano-sized grains of calcium phosphate have reignited interest in loadbearing applications. Compared with traditional calcium phosphate based materials, nano-scaled calcium phosphate materials have shown many advantages, such as improved sinterability, enhanced mechanical properties and better bioactivity. Bose et al. [81] reported nanostructured HA ceramics with average grain sizes ranging from $168 \pm 86$ $\mathrm{nm}$ to $1.16 \pm 0.17 \mu \mathrm{m}$ were processed using microwave sintering. The HA compact with smaller sized grains 

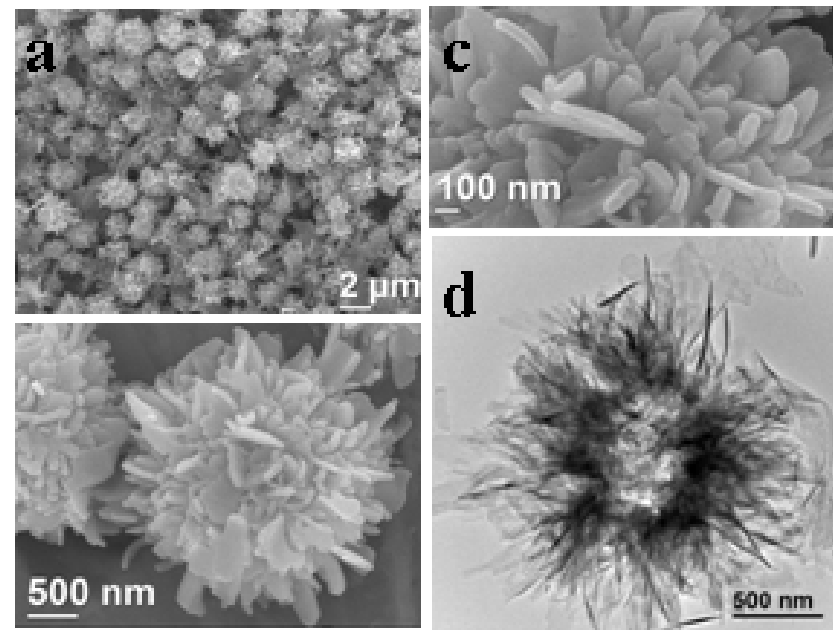

Fig. 5 SEM and TEM micrographs of the sample prepared using $3.5 \mathrm{~g}$ L PLA-PEG and $20 \mathrm{mM}[\mathrm{Ca} 2+]$ by microwave heating at $120 \mathrm{oC}$ for 60 min. Reprinted from Ref. [62].
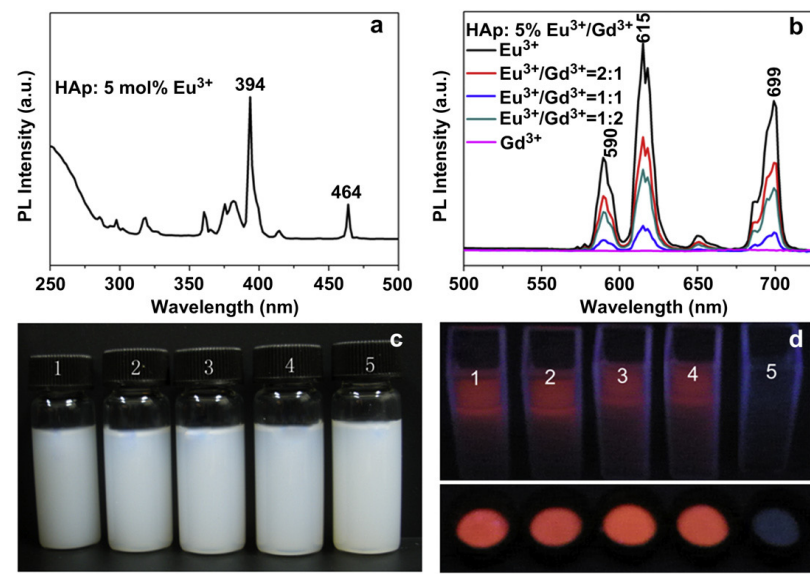

Fig. 7 Room-temperature excitation spectrum (a) and PL emission spectra (b) of Eu3+/Gd3+-HAp nanorods; (c) the photograph of dispersed solutions of Eu3+/Gd3+-HAp nanorods in deionized water; and (d) the PL photograph of Eu3t/Gd3teHAp nanorods powder and their dispersed solutions under irradiation by UV lamp (365 nm). The doping concentrations of Eu3 + and $\mathrm{Gd} 3+$ were $5 \mathrm{~mol} \%$ relative to $\mathrm{Ca} 2+$, and the ratios of $\mathrm{Eu} 3+$ to $\mathrm{Gd} 3+$ in (c) and (d) from 1 to 5 were 1:0, $2: 1,1: 1,1: 2$ and $0: 1$. Reprinted from Ref [98].

showed the higher compressive strength. The decrease in strength due to increase in grain size was less prominent in HA than what would be predicted by the classical Hall-Petch equation. An increase in bone cell adhesion and proliferation with decreasing grain size was observed. Lin et al. [82] reported that the maximal values of the bending strength, elastic module, Vickers hardness and compressive strength of the samples fabricated from nano-size $\beta$-TCP powders were more than twotimes those of bioceramics obtained from micro-size $\beta$-TCP powders. The degradability of $\beta$-TCP ceramics sintered from nanosized powders was just about onequarter of that sintered from microsized powders, and the degradability of could be adjusted by the particle sizes.

Beside the ceramic materials, porous 3-D nanocomposites of calcium phosphate and polymer can also be employed in bone repair. Cui et al. [83,84] developed nanosized

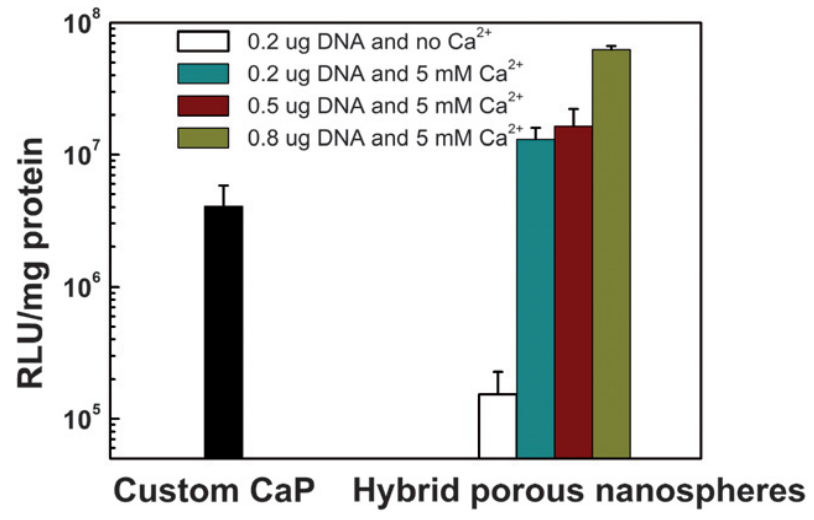

Fig. 6 Luciferase activity in COS-7 cells transfected with pGL3-control vector complexed with calcium phosphate/PLGA-mPEG hybrid porous nanospheres. The amount of DNA in the legend was for a well of 96-well plate. The final concentration of $\mathrm{Ca} 2+$ was $5 \mathrm{mM}$. The amount of Calcium phosphate/PLGAmPEG hybrid porous nanospheres was $0.2 \mathrm{mg}$ per well. Custom Calcium phosphate transfection was carried out according to the literature. Reprinted from Ref. [49]

hierarchical self-assembly of mineralized collagen nanofibrils that mimicked the nanostructure of bones. HA crystals grew on the surfaces of the collagen fibrils. The mineralized collagen fibrils aligned parallel to each other to form mineralized collagen fibers. The investigation and simulation of naturally occurring fibril structures can offer some new ideas in the design and fabrication of new functional materials for applications such as bone grafts or for use as scaffolds in tissue engineering and biomimetic engineering materials [84]. Li et al. [85] reported porous 3 -D nanocomposites of n-HA/PA66 as tissue engineering scaffold material prepared by co-precipitation method. The composite had excellent mechanical properties close to that of natural bone. The porous material had not only macropores but also micropores on the walls of the macropores. Such biomaterial with well-controlled composition and porous structure can be a good bone repair materials and can provide a standard scaffold for investigating the cell/material interaction in tissue engineering.

Our group has reported HA fabrics which can be used as the bone tissue engineering scaffold. The single-phase HA fabrics, tubular morphologies or aligned nanofiber arrays were obtained through thermal treatment of corresponding electrospun HA/PVP composite nanofibers [78]. The as-prepared HA fabric was used as the substrate for MSCs culture. The results exhibited that the HA scaffold was biocompatible, and the cells could attach well on the HA fabric and combine tightly with HA fibers. In addition, the ACP/PDLLA composite nanofibers were also fabricated through electrospinnig [79]. The ACP/PDLLA composite nanofiber matrix showed a good biocompatibility when osteoblast-like MG63 cells were seeded. The ACP/PDLLA composite nanofibers exhibited a fast mineralization behavior in the simulated body fluid.

\subsection{Drug/gene delivery}

Bone not only acts as a reservoir for calcium and phosphate, but also stores growth factors, fatty acids and 
is involved in buffering the blood by controlled release of alkaline salts [86]. Calcium phosphate as the inorganic constituent in bone is biocompatible, therefore, synthetic calcium phosphate materials are ideal biomaterials for drug/gene delivery.

Our group reported a flower-like nanostructured HA hollow microspheres fabricated via a rapid microwaveassisted hydrothermal route, and explored its application as anticancer drug carrier for cellular delivery of mitoxantrone (Fig. 5) [62]. The materials exhibited sustained drug release behavior in vitro, and the intracellular drug distribution tests indicated that the MIT loaded in carriers could enter the cells efficiently. Cai et al.[87] reported hollow-structured calcium phosphate nanospheres which could be transformed into pin-shaped crystallites under ultrasonic treatment. The release of encapsulated compounds could be on/off triggered and the kinetics was precisely regulated by the power density, duty cycle and application time of ultrasound.

It was reported that calcium ions increased the in vitro transfection efficiency of pDNA-cationic liposome complexes from three- to 20-fold.[88] In the review by Maitra, calcium ions were described to play an important role in endosomal escape, cytosolic stability and enhanced nuclear uptake of DNA through nuclear pore complexes. The special role of exogenous calcium ions to overcome obstacles in practical realization of this field suggests that calcium phosphate nanoparticles can be designated as second-generation nonviral vectors for gene therapy [89].

Early methods of gene transfer using calcium phosphate materials, involved coprecipitating DNA with calcium phosphate [90]. But irregular particle morphology and large size impeded using calcium phosphate precipitate as a carrier for DNA. This group reported the preparation of calcium phosphate/PLGA-mPEG hybrid porous nanospheres and their application in gene delivery [49]. Calcium phosphate/PLGA-mPEG hybrid porous nanospheres exhibited very high DNA loading capacity (approximately 40-150 times higher than that of the mesoporous silica vectors reported) and good transfection efficiency. Unlike the traditional calcium phosphate transfection procedure in which calcium phosphate usually precipitates in the presence of DNA molecules, the reported method consisted of two steps: preparation of calcium phosphate nanostructured vectors in the absence of DNA, and then loading and transfection of DNA. HA nanorods were also used as the gene carrier (Fig. 6) [52]. The results demonstrated a significant enhancement of DNA adsorptive capacity of HA nanorods compared with traditional DNA adsorbents. And adsorbed DNA could be desorbed reversibly from HA nanorods with high eluted percentage.

\subsection{Multifunctional nanostructured calcium phosphate}

The development of multifunctional nanostructured systems holds a promise for the future of clinical treatments to enhance therapeutic efficacy [91, 92]. It is highly desirable to develop novel multifunctional nanostructured systems that can achieve simultaneous in vivo imaging and treatment. Due to the biocompatible nature, HA nanostructures may serve as the ideal candidate for both bio-imaging and drug delivery. Recently, the research on dual or multifunctional nanostructured HA systems for biomedical applications has become a hot topic [93-97].

Our group reported a facile method for the preparation of ACP/PLA-mPEG hybrid nanoparticles which were successfully used as the precursor for preparation of ACP porous nanospheres [99]. Photoluminescence function of ACP porous nanospheres was achieved by europium doping. The experimental results of photoluminescence, cytotoxicity as well as in vitro drug loading and release showed that the as-prepared Eu3+:ACP porous nanospheres were biocompatible and bioactive with favorable properties of photoluminescence, drug loading and drug release, implying $\mathrm{Eu}^{3+}$ :ACP porous nanospheres are a new kind of promising biomaterial with bi-functions of both luminescence and drug release. Multifunctional $\mathrm{Eu}^{3+} / \mathrm{Gd}^{3+}$ dual-doped HA nanorods were prepared by a rapid microwave-assisted method [98]. The dual-doping of $\mathrm{Eu}^{3+} / \mathrm{Gd}^{3+}$ endowed HA nanorods with photoluminescent and magnetic multifunctions. The PL intensity and magnetization of doped HA nanorods could be adjusted by varying $\mathrm{Eu}^{3+}$ and $\mathrm{Gd}^{3+}$ concentrations (Fig. 7). The as-prepared $\mathrm{Eu}^{3+} /$ $\mathrm{Gd}^{3+}$ doped HA nanorods exhibited inappreciable toxicity to the cells in vitro, and showed a high drug adsorption capacity and sustained drug release using ibuprofen as a model drug. The noninvasive visualization of nude mice with subcutaneous injection indicated that the $\mathrm{Eu}^{3+} / \mathrm{Gd}^{3+}$ doped HA nanorods with the photoluminescent function are suitable for in vivo imaging. The $\mathrm{Eu}^{3+} / \mathrm{Gd}^{3+}$ dualdoped HA nanorods are promising for applications in the biomedical fields such as multifunctional drug delivery systems with imaging-guidance. Furthermore, Adair et al. [100-102] reported calcium phosphate nanocomposite particles that encapsulated both fluorophores and chemotherapeutics, within a 20-30 nm diameter, $\mathrm{pH}$ responsive, nonagglomerating, nontoxic calcium phosphate nanoparticle matrix. Encapsulation of imaging agents and drugs in calcium phosphate nanoparticles has a potential as a nontoxic, bioresorbable vehicle for drug delivery to cells and tumors.

\section{Conclusion}

To optimize and achieve better performances, controlling the structure and size of nanostructured calcium phosphate materials has become a hot field. Up to now, many methods have been reported to prepare nanostructured calcium phosphates, such as coprecipitation, sol-gel synthesis, hydrothermal reaction, mechanical milling, etc. Nanostructured calcium phosphate materials with a variety of morphologies including nanorods, nanosheets, nanoparticles, biomimic structure, novel 3-D structures, have been 
successfully obtained. The performances of calcium phosphates in application depend greatly on their morphologies, structure and chemical compositions. These nanostructured calcium phosphates are promising biomaterials for applications in tissue engineering scaffolds, drug/gene delivery and other medical areas. Furthermore, it is highly desirable to design and prepare novel nanostructured multifunctional systems based on calcium phosphates to achieve simultaneous in vitro/vivo imaging and treatment.

\section{Acknowledgements}

The financial support from the National Natural Science Foundation of China (51172260, 51102258), Science and Technology Commission of Shanghai (1052nm06200, 11nm0506600, 11ZR1441800), Chinese Nano-973 Project (2010CB933901) is gratefully acknowledged.

\section{References}

1. Gassmann T. The preparation of a complex salt corresponding to apatite-typus and its relations to the constitution of bones. $H-S Z$ Physiol Chem 1913; 83: 403-8.

2. Fratzl P, Gupta HS, Paschalis EP, Roschger P. Structure and mechanical quality of the collagen-mineral nano-composite in bone. J Mater Chem. 2004; 14: 2115-23.http://dx.doi.org/10.1039/ b402005g

3. Tzaphlidou M. Bone Architecture Collagen Structure and Calcium/ Phosphorus Maps. J Biol Phys. 2008; 34: 39-49.http://dx.doi. org/10.1007/s10867-008-9115-y

4. Hoffler CE, Guo XE, Zysset PK, Goldstein SA. An application of nanoindentation technique to measure bone tissue lamellae properties. J Biomech Eng-T Asme 2005; 127: 1046-53. http://dx.doi.org/10.1115/1.2073671

5. Bembey AK, Bushby AJ, Boyde A, Ferguson VL, Oyen ML. Hydration effects on the micro-mechanical properties of bone. $J$ Mater Res.2006; 21:1962-8.http://dx.doi.org/10.1557/jmr.2006.0237

6. Weiner S, Wagner HD. The material bone Structure mechanical function relations. Annu Rev Mater Sci. 1998; 28:271-98. http://dx.doi.org/10.1146/annurev.matsci.28.1.271

7. Weiner S, Traub W, Wagner HD. Lamellar bone structure-function relations. J Struct Biol. 1999, 126, 241-55.http://dx.doi.org/10.1006/ jsbi.1999.4107

8. Rubin MA, Jasiuk L, Taylor J, Rubin J, Ganey T, Apkarian RP. TEM analysis of the nanostructure of normal and osteoporotic human trabecular bone. Bone. 2003; 33: 270-282.http://dx.doi. org/10.1016/S8756-3282(03)00194-7

9. Pasteris JD, Wopenka B, Valsami-Jones E. Bone and tooth mineralization Why apatite? Elements. 2008; 4: 97-104. http://dx.doi.org/10.2113/GSELEMENTS.4.2.97

10.Dorozhkin SV. Nanosized and nanocrystalline calcium orthophosphates. Acta Biomater. 2010;6:715-34. http://dx.doi.org/10.1016/j.actbio.2009.10.031

11.Dorozhkin SV. Bioceramics of calcium orthophosphates. Biomaterials. 2010;31:1465-85.http://dx.doi.org/10.1016/ j.biomaterials.2009.11.050

12. Dorozhkin SV. Calcium orthophosphate-based biocomposites and hybrid biomaterials. J Mater Sci. 2009; 44: 2343-87.http://dx.doi. org/10.1007/s10853-008-3124-x

13. Ong JL, Chan DCN. Hydroxyapatite and their use as coatings in dental implants A review. Crit Rev Biomed Eng. 2000; 28: 667a-707a.

14. Cai YR, Tang RK. Calcium phosphate nanoparticles in biomineralization and biomaterials. J Mater Chem. 2008; 18: 3775-87. http://dx.doi.org/10.1039/b805407j

15. Tas AC. Synthesis of biomimetic Ca-hydroxyapatite powders at $37{ }^{\circ} \mathrm{C}$ in synthetic body fluids. Biomaterials. 2000; 21:1429-38. http://dx.doi.org/10.1016/S0142-9612(00)00019-3

16. Suchanek WL, Byrappa K, Shuk P, Riman RE, Janas VF, TenHuisen KS. Mechanochemical-hydrothermal synthesis of calcium phosphate powders with coupled magnesium and carbonate substitution. J Solid State Chem. 2004; 177: 793-9.http://dx.doi. org/10.1016/j.jssc.2003.09.012

17. Suchanek WL, Shuk P, Byrappa K, Riman RE, TenHuisen KS, Janas VF. Mechanochemical-hydrothermal synthesis of carbonated apatite powders at room temperature. Biomaterials. 2002; 23:699710.http://dx.doi.org/10.1016/S0142-9612(01)00158-2

18. Gu SY, Zhan H, Ren J, Zhou XY. Sol-gel synthesis and characterisation of nano-sized hydroxyapatite powders and hydroxyapatite/poly(D,L-lactide-co-glycolide) composite scaffolds. Polym Polym Compos. 2007; 15:137-44.

19. Jadalannagari S, More S, Kowshik M, Ramanan SR. Low temperature synthesis of hydroxyapatite nano-rods by a modified sol-gel technique. Mat Sci Eng C-Mater. 2011; 31:1534-8.http:// dx.doi.org/10.1016/j.msec.2011.07.001

20. Lee JG, Hong SM, Park JJ, Lee MK, Hong SJ, Joo UH, Rhee CK. High energy ball-mill behavior of titania plus hydroxyapatite composite nano-powders. Mater Charact. 2010; 61:1290-3.http:// dx.doi.org/10.1016/j.matchar.2010.08.004

21. Niu JL. Hydrothermal synthesis of nano-crystalline hydroxyapatite. Bioceramics. 2007; 19:330-332, 247-50.

22. Stupp SI, Ciegler GW. Organoapatites materials for artificial bone. I. Synthesis and microstructure. J Biomed Mater Res. 1992; 26:16983.http://dx.doi.org/10.1002/jbm.820260204

23. Poinern GE, Brundavanam RK, Mondinos N, Jiang ZT. Synthesis and characterisation of nanohydroxyapatite using an ultrasound assisted method. Ultrason Sonochem. 2009; 16: 469-74.http:// dx.doi.org/10.1016/j.ultsonch.2009.01.007

24. LeGeros RZ. Biodegradation and bioresorption of calcium phosphate ceramics. Clin Mater 1993; 14:65-88.http://dx.doi. org/10.1016/0267-6605(93)90049-D

25. Chan CK, Kumar TSS, Liao S, Murugan R, Ngiam M, Ramakrishman S. Biomimetic nanocomposites for bone graft applications. Nanomedicine-Uk. 2006; 1: 177-88.http://dx.doi. org/10.2217/17435889.1.2.177

26. Mikolajczyk T, Rabiej S, Bogun M. Analysis of the structural parameters of polyacrylonitrile fibers containing nanohydroxyapatite. J Appl Polym Sci. 2006; 101:760-5.http:// dx.doi.org/10.1002/app.23978

27. Kalita SJ, Bhardwaj A, Bhatt HA. Nanocrystalline calcium phosphate ceramics in biomedical engineering. Mat Sci Eng C-Bio S. 2007; 27: 441-9.http://dx.doi.org/10.1016/j.msec.2006.05.018

28. Zhou H, Lee J. Nanoscale hydroxyapatite particles for bone tissue engineering. Acta Biomater. 2011: 7:2769-81.http://dx.doi. org/10.1016/j.actbio.2011.03.019

29. Zhang CM, Yang J, Quan ZW, Yang PP, Li CX, Hou ZY, Lin J. Hydroxyapatite Nano- and Microcrystals with Multiform Morphologies Controllable Synthesis and Luminescence Properties. Cryst Growth Des. 2009; 9:2725-33.http://dx.doi.org/10.1021/ cg801353n

30. Lai C, Tang SQ, Wang YJ, Wei K. Formation of calcium phosphate nanoparticles in reverse microemulsions. Mater Lett. 2005; 59:2104.http://dx.doi.org/10.1016/j.matlet.2004.08.037

31. Jevtic M, Mitric M, Skapin S, Jancar B, Ignjatovic N, Uskokovic D. Crystal structure of hydroxyapatite nanorods synthesized by sonochemical homogeneous precipitation. Cryst Growth Des. 2008; 8:2217-22.http://dx.doi.org/10.1021/cg7007304

32. Zhang HB, Zhou KC, Li ZY, Huang SP. Plate-like hydroxyapatite nanoparticles synthesized by the hydrothermal method. J Phys Chem Solids 2009, 70, 243-8.http://dx.doi.org/10.1016/ j.jpcs.2008.10.011

33. Ito H, Oaki Y, Imai H. Selective synthesis of various nanoscale morphologies of hydroxyapatite via an intermediate phase. Cryst Growth Des. 2008; 8:1055-9.http://dx.doi.org/10.1021/cg070443f

34. Lin KL, Chang J, Liu XG, Chen L, Zhou YL. Synthesis of elementsubstituted hydroxyapatite with controllable morphology and chemical composition using calcium silicate as precursor. Cryst Eng Comm. 2011; 13:4850-55.http://dx.doi.org/10.1039/c0ce00835d

35. Shum HC, Bandyopadhyay A, Bose S, Weitz DA. Double emulsion droplets as microreactors for synthesis of mesoporous hydroxyapatite. Chem Mater. 2009; 21:5548-55.http://dx.doi. org/10.1021/cm9028935

36. Yoshimura M, Suda H, Okamoto K, Ioku K. Hydrothermal synthesis 
of biocompatible whiskers. J Mater Sci. 1994; 29: 3399-402. http://dx.doi.org/10.1007/BF00352039

37. Chen F, Zhu YJ, Wang KW, Zhao KL. Surfactant-free solvothermal synthesis of hydroxyapatite nanowire/nanotube ordered arrays with biomimetic structures. Cryst Eng Comm 2011; 13:1858-63. http://dx.doi.org/10.1039/c0ce00574f

38. Zhan JH, Tseng YH, Chan JCC, Mou CY. Biomimetic formation of hydroxyapatite nanorods by a single-crystal-to-single-crystal transformation. Adv Funct Mater 2005; 15:2005-10.http://dx.doi. org/10.1002/adfm.200500274

39. Wei K, Wang YJ, Lai C, Ning CY, Wu DX, Wu G, Zhao NR, Chen $\mathrm{XF}, \mathrm{Ye}$ RS. Synthesis and characterization of hydroxyapatite nanobelts and nanoparticles. Mater Lett. 2005; 59: 220-5. http://dx.doi.org/10.1016/j.matlet.2004.08.034

40. Lin KL, Chang J, Zhu YJ, Wu W, Cheng GF, Zeng Y, Ruan ML. A facile one-step surfactant-free and low-temperature hydrothermal method to prepare uniform 3D structured carbonated apatite flowers. Cryst Growth Des. 2009; 9:177-81.http://dx.doi.org/10.1021/ $\operatorname{cg} 800129 \mathrm{u}$

41. Ma MG, Zhu YJ, Chang J. Monetite formed in mixed solvents of water and ethylene glycol and its transformation to hydroxyapatite. J Phys Chem B. 2006; 110:14226-30.http://dx.doi.org/10.1021/ jp061738r

42. He QJ, Huang ZL, Liu Y, Chen W, Xu T. Template-directed one-step synthesis of flowerlike porous carbonated hydroxyapatite spheres. Mater Lett. 2007; 61:141-3.http://dx.doi.org/10.1016/ j.matlet.2006.04.082

43. Mochales C, El Briak-BenAbdeslam H, Ginebra MP, Terol A, Planell JA, Boudeville P. Dry mechanochemical synthesis of hydroxyapatites from DCPD and $\mathrm{CaO}$ influence of instrumental parameters on the reaction kinetics. Biomaterials. 2004: 25:1151-8. http://dx.doi.org/10.1016/j.biomaterials.2003.08.002

44. Rivera EM, Araiza M, Brostow W, Castano VM, Diaz-Estrada JR, Hernandez, R.; Rodriguez, J. R. Synthesis of hydroxyapatite from eggshells. Mater Lett. 1999; 41:128-134.http://dx.doi.org/10.1016/ S0167-577X(99)00118-4

45. Pang YX, Bao X. Influence of temperature, ripening time and calcination on the morphology and crystallinity of hydroxyapatite nanoparticles. J Eur Ceram Soc. 2003; 23:1697-704.http://dx.doi. org/10.1016/S0955-2219(02)00413-2

46. Lopez-Macipe A, Gomez-Morales J, Rodriguez-Clemente R. Nanosized hydroxyapatite precipitation from homogeneous calcium/citrate/phosphate solutions using microwave and conventional heating. Adv Mater. 1998; 10:49-53.http:// dx.doi.org/10.1002/(SICI)1521-4095(199801)10:1<49::AIDADMA49>3.0.CO;2-R

47. Boanini E, Fini M, Gazzano M, Bigi A. Hydroxyapatite nanocrystals modified with acidic amino acids. Eur J Inorg Chem. 2006; 4821-6. http://dx.doi.org/10.1002/ejic.200600423

48. Zhang J, Gao X, Song BC, Wang ZF, Lu WW. A novel technique to synthesize hydroxyapatite whiskers. Mater Lett. 2008; 62:1162-4. http://dx.doi.org/10.1016/j.matlet.2007.07.067

49. Wang KW, Zhou LZ, Sun Y, Wu GJ, Gu HC, Duan YR, Chen F, Zhu YJ. Calcium phosphate/PLGA-mPEG hybrid porous nanospheres A promising vector with ultrahigh gene loading and transfection efficiency. J Mater Chem. 2010; 20:1161-6. http://dx.doi.org/10.1039/b917441a

50. Wang KW, Zhu YJ, Chen F, Cao SW. Calcium phosphate/block copolymer hybrid porous nanospheres Preparation and application in drug delivery. Mater Lett. 2010; 64:2299-301.http://dx.doi. org/10.1016/j.matlet.2010.07.060

51. Tang QL, Zhu YJ, Duan YR, Wang Q, Wang KW, Cao SW, Chen F, Wu J. Porous nanocomposites of PEG-PLA/calcium phosphate room-temperature synthesis and its application in drug delivery. Dalton T. 2010; 39:4435-9.http://dx.doi.org/10.1039/b925779a

52. Wu GJ, Zhou LZ, Wang KW, Chen F, Sun Y, Duan YR, Zhu YJ, Gu HC. Hydroxylapatite nanorods An efficient and promising carrier for gene transfection. J Colloid Interf Sci. 2010; 345: 427-32. http://dx.doi.org/10.1016/j.jcis.2010.01.048

53. Ma MY, Zhu YJ, Li L, Cao SW. Nanostructured porous hollow ellipsoidal capsules of hydroxyapatite and calcium silicate preparation and application in drug delivery. J Mater Chem 2008; 18:2722-27.http://dx.doi.org/10.1039/b800389k
54. Bigi A, Boanini E, Walsh D, Mann S. Morphosynthesis of octacalcium phosphate hollow microspheres by polyelectrolytemediated crystallization. Angew Chem Int Edit 2002, 41, 2163-6. http://dx.doi.org/10.1002/1521-3773(20020617)41:12<2163::AIDANIE2163>3.0.CO;2-G

55. Wang YS, Hassan MS, Gunawan P, Lau R, Wang X, Xu R. Polyelectrolyte mediated formation of hydroxyapatite microspheres of controlled size and hierarchical structure. J Colloid Interf Sci 2009; 339: 69-77.http://dx.doi.org/10.1016/j.jcis.2009.07.023

56. Schmidt HT, Ostafin AE. Liposome directed growth of calcium phosphate nanoshells. Adv Mater 2002; 14:532-5.http:// dx.doi.org/ 10.1002/1521-4095(20020404)14:7<532::AIDADMA532>3.0 $\mathrm{CO} ; 2-4$

57. Tjandra W, Ravi P, Yao J, Tam KC. Synthesis of hollow spherical calcium phosphate nanoparticles using polymeric nanotemplates. Nanotechnology. 2006; 17:5988-94.http://dx.doi.org/10.1088/09574484/17/24/014

58. Lin KL, Liu XG, Chang J, Zhu YJ. Facile synthesis of hydroxyapatite nanoparticles, nanowires and hollow nanostructured microspheres using similar structured hard-precursors. Nanoscale 2011; 3: 3052-5.http://dx.doi.org/10.1039/c1nr10334b

59. Liu JB, Li KW, Wang H, Zhu MK, Yan H. Rapid formation of hydroxyapatite nanostructures by microwave irradiation. Chem Phys Lett 2004; 396:429-32.http://dx.doi.org/10.1016/ j.cplett.2004.08.094

60. Cheng XK, Huang ZL, Li JQ, Liu Y, Chen CL, Chi RA, Hu YH Self-assembled growth and pore size control of the bubble-template porous carbonated hydroxyapatite microsphere. Cryst Growth Des 2010; 10: 1180-8.http://dx.doi.org/10.1021/cg901088c

61. Ma MG, Zhu YJ, Chang J. Monetite formed in mixed solvents of water and ethylene glycol and its transformation to hydroxyapatite. J Phys Chem B. 2006; 110:14226-30.http://dx.doi.org/10.1021/ jp061738r

62. Wang KW, Zhu YJ, Chen XY, Zhai WY, Wang Q, Chen F, Chang JA, Duan YR. Flower-like hierarchically nanostructured hydroxyapatite hollow spheres facile preparation and application in anticancer drug cellular delivery. Chem-Asian J. 2010; 5: 2477-82. http://dx.doi.org/10.1002/asia.201000463

63. Peytcheva A, Colfen H, Schnablegger H, Antonietti M. Calcium phosphate colloids with hierarchical structure controlled by polyaspartates. Colloid Polym Sci. 2002; 280:218-27.http://dx.doi. org/10.1007/s00396-001-0600-0

64. Wang LJ, Guan XY, Yin HY, Moradian-Oldak J, Nancollas GH. Mimicking the self-organized microstructure of tooth enamel. $J$ Phys Chem C. 2008; 112:5892-9.http://dx.doi.org/10.1021/ jp077105+

65. Kumar R, Prakash KH, Cheang P, Gower L, Khor KA. Chitosanmediated crystallization and assembly of hydroxyapatite nanoparticles into hybrid nanostructured films. J R Soc Interface. 2008; 5: 427-39.http://dx.doi.org/10.1098/rsif.2007.1141

66. Furuichi K, Oaki Y, Imai H. Preparation of nanotextured and nanoribrous hydroxyapatite through dicalcium phosphate with gelatin. Chem Mater. 2006; 18:229-34.http://dx.doi.org/10.1021/ $\mathrm{cm} 052213 \mathrm{z}$

67. Zhang JL, Jiang DL, Zhang JX, Lin QL, Huang ZR. Synthesis of dental enamel-like hydroxyapaptite through solution mediated solidstate conversion. Langmuir. 2010; 26:2989-94.http://dx.doi. org/10.1021/la9043649

68. Yao X, Yao HW, Li GY, Li YT. Biomimetic synthesis of needle-like nano-hydroxyapatite templated by double-hydrophilic block copolymer. J Mater Sci. 2010; 45:1930-36.http://dx.doi.org/10.1007/ s10853-009-4182-4

69. Zhang YZ, Reddy VJ, Wong SY, Li X, Su B, Ramakrishna S, Lim CT. Enhanced biomineralization in osteoblasts on a novel electrospun biocomposite nanofibrous substrate of hydroxyapatite/ collagen/chitosan. Tissue Eng Pt A. 2010; 16:1949-60.http://dx.doi. org/10.1089/ten.tea.2009.0221

70. Habibovic P, Bassett DC, Doillon CJ, Gerard C, Mckee MD, Barralet JE. Collagen biomineralization in vivo by sustained release of inorganic phosphate ions. Adv Mater. 2010; 22:1858-62.http:// dx.doi.org/10.1002/adma.200902778

71. Jayasuriya AC, Kibbe S. Rapid biomineralization of chitosan microparticles to apply in bone regeneration. J Mater Sci-Mater M 
2010; 21:393-8.http://dx doi.org/10.1007/s10856-009-3874-2

72. Sailaja GS, Sreenivasan K, Yokogawa Y, Kumary TV, Varma HK. Bioinspired mineralization and cell adhesion on surface functionalized poly(vinyl alcohol) films. Acta Biomater. 2009; 5: 1647-55.http://dx.doi.org/10.1016/j.actbio.2008.12.005

73. Jongpoiboonkit L, Franklin-Ford T, Murphy WL. Mineral-coated polymer microspheres for controlled protein binding and release. Adv Mater. 2009; 21:1960-3.http://dx.doi.org/10.1002/ adma.200801808

74. Lin KL, Zhou YL, Zhou Y, Qu HY, Chen F, Zhu YJ, Chang J. Biomimetic hydroxyapatite porous microspheres with co-substituted essential trace elements Surfactant-free hydrothermal synthesis, enhanced degradation and drug release. J Mater Chem. 2011; 21 : 16558-65.http://dx.doi.org/10.1039/c1jm12514a

75. Liao S, Li BJ, Ma ZW, Wei H, Chan C, Ramakrishna S. Biomimetic electrospun nanofibers for tissue regeneration. Biomed Mater. 2006; 1:45-53.http://dx.doi.org/10.1088/1748-6041/1/3/R01

76. Dai XS, Shivkumar S. Electrospinning of hydroxyapatite fibrous mats. Mater Lett. 2007; 61:2735-8.http://dx.doi.org/10.1016/ j.matlet.2006.07.195

77. Dai XS, Shivkumar S. Electrospinning of PVA-calcium phosphate sol precursors for the production of fibrous hydroxyapatite. $J$ Am Ceram Soc. 2007; 90:1412-9.http://dx.doi.org/10.1111/j.15512916.2007.01569.x

78. Chen F, Tang QL, Zhu YJ, Wang KW, Zhang ML, Zhai WY, Chang JA. Hydroxyapatite nanorods/poly(vinyl pyrolidone) composite nanofibers, arrays and three-dimensional fabrics Electrospun preparation and transformation to hydroxyapatite nanostructures. Acta Biomater. 2010; 6:3013-20.http://dx.doi. org/10.1016/j.actbio.2010.02.015

79. Ma Z, Chen F, Zhu YJ, Cui T, Liu XY. Amorphous calcium phosphate/poly(D,L-lactic acid) composite nanofibers Electrospinning preparation and biomineralization. J Colloid Interf Sci 2011; 359:371-9.http://dx.doi.org/10.1016/j.jcis.2011.04.023

80. Stupp SI, Braun PV. Molecular manipulation of microstructures Biomaterials, ceramics, and semiconductors. Science. 1997; 277: 1242-8.http://dx.doi.org/10.1126/science.277.5330.1242

81. Bose S, Dasgupta S, Tarafder S, Bandyopadhyay A. Microwaveprocessed nanocrystalline hydroxyapatite Simultaneous enhancement of mechanical and biological properties. Acta Biomater 2010; 6:3782-90.http://dx.doi.org/10.1016/ j.actbio.2010.03.016

82. Lin KL, Chang JA, Lu JX, Wu W, Zeng Y. Properties of beta$\mathrm{Ca}_{3}\left(\mathrm{PO}_{4}\right)_{2}$ bioceramics prepared using nano-size powders. Ceram Int 2007; 33:979-85.http://dx.doi.org/10.1016/j.ceramint.2006. 02.011

83. Zhang W, Liao SS, Cui FZ. Hierarchical self-assembly of nanofibrils in mineralized collagen. Chem Mater. 2003; 15:3221-6. http://dx.doi.org/10.1021/cm030080g

84. Cui FZ, Li Y, Ge J. Self-assembly of mineralized collagen composites. Mat Sci Eng R 2007; 57:1-27.http://dx.doi.org/10.1016/ j.mser.2007.04.001

85. Jie W, Li Y. Tissue engineering scaffold material of nano-apatite crystals and polyamide composite. Eur Polym J .2004; 40:509-15. http://dx.doi.org/10.1016/j.eurpolymj.2003.10.028

86. Uskokovic V, Uskokovic DP. Nanosized hydroxyapatite and other calcium phosphates Chemistry of formation and application as drug and gene delivery agents. J Biomed Mater Res B 2011; 96:152-91. http://dx.doi.org/10.1002/jbm.b.31746

87. Cai YR, Pan HH, Xu XR, Hu QH, Li L, Tang RK. Ultrasonic controlled morphology transformation of hollow calcium phosphate nanospheres A smart and biocompatible drug release system. Chem Mater 2007; 19:3081-3.http://dx.doi.org/10.1021/cm070298t

88. Lam AMI, Cullis PR. Calcium enhances the transfection potency of plasmid DNA-cationic liposome complexes. Bba-Biomembranes 2000; 1463:279-90.http://dx.doi.org/10.1016/S00052736(99)00219-9
89. Maitra A. Calcium phosphate nanoparticles second-generation nonviral vectors in gene therapy. Expert Rev Mol Diagn. 2005; 5:893-905.http://dx.doi.org/10.1586/14737159.5.6.893

90. Orrantia E, Chang PL. Intracellular-Distribution of DNA Internalized through Calcium-Phosphate Precipitation. Exp Cell Res 1990; 190:170-4.http://dx.doi.org/10.1016/0014-4827(90)90181-9

91. Shi DL. Integrated multifunctional nanosystems for medical diagnosis and treatment. Adv Funct Mater. 2009; 19:3356-73. http://dx.doi.org/10.1002/adfm.200901539

92. Park K, Lee S, Kang E, Kim K, Choi K, Kwon IC. New generation of multifunctional nanoparticles for cancer imaging and therapy. Adv Funct Mater 2009; 19:1553-66.http://dx.doi.org/10.1002/ adfm.200801655

93. Al-Kattan A, Dufour P, Dexpert-Ghys J, Drouet C. Preparation and physicochemical characteristics of luminescent apatite-based colloids. J Phys Chem C 2010, 114, 2918-24.http://dx.doi. org/10.1021/jp910923g

94. Zhang CM, Li CX, Huang SS, Hou ZY, Cheng ZY, Yang PP, Peng C, Lin J. Self-activated luminescent and mesoporous strontium hydroxyapatite nanorods for drug delivery. Biomaterials. 2010; 31 : 3374-83.http://dx.doi.org/10.1016/j.biomaterials.2010.01.044

95. Yang PP, Quan ZW, Li CX, Kang XJ, Lian HZ, Lin J. Bioactive, luminescent and mesoporous europium-doped hydroxyapatite as a drug carrier. Biomaterials. 2008; 29:4341-7.http://dx.doi. org/10.1016/j.biomaterials.2008.07.042

96. Ashokan A, Menon D, Nair S, Koyakutty M. A molecular receptor targeted, hydroxyapatite nanocrystal based multi-modal contrast agent. Biomaterials. 2010; 31:2606-16.http://dx.doi.org/10.1016/ j.biomaterials.2009.11.113

97. Epple M, Neumeier M, Hails LA, Davis SA, Mann S. Synthesis of fluorescent core-shell hydroxyapatite nanoparticles. J Mater Chem. 2011; 21:1250-4.http://dx.doi.org/10.1039/c0jm02264k

98. Chen F, Huang P, Zhu YJ, Wu J, Zhang CL, Cui DX. The photoluminescence, drug delivery and imaging properties of multifunctional $\mathrm{Eu}^{3+} / \mathrm{Gd}^{3+}$ dual-doped hydroxyapatite nanorods. Biomaterials. 2011; 32:9031-9.http://dx.doi.org/10.1016/ j.biomaterials.2011.08.032

99. Chen F, Zhu YJ, Zhang KH, Wu J, Wang KW, Tang QL, Mo XM Europium-doped amorphous calcium phosphate porous nanospheres preparation and application as luminescent drug carriers. Nanoscale Res Lett. 2010; 6:No. 67.

100.Kester M, Heakal Y, Fox T, Sharma A, Robertson GP, Morgan T T, Altinoglu EI, Tabakovic A, Parette MR, Rouse SM, Ruiz-Velasco $\mathrm{V}$, Adair JH. Calcium phosphate nanocomposite particles for in vitro imaging and encapsulated chemotherapeutic drug delivery to cancer cells. Nano Lett. 2008; 8: 4116-21.http://dx.doi.org/10.1021/ n1802098g

101.Morgan TT, Muddana HS, Altinoglu EI, Rouse SM, Tabakovic A, Tabouillot T, Russin TJ, Shanmugavelandy SS, Butler PJ, Eklund PC, Yun JK, Kester M, Adair JH. Encapsulation of organic molecules in calcium phosphate nanocomposite particles for intracellular imaging and drug delivery. Nano Lett. 2008; 8:4108-15. http://dx.doi.org/10.1021/n18019888

102.Altinoglu EI, Russin TJ, Kaiser JM, Barth BM, Eklund PC, Kester M, Adair JH. Near-infrared emitting fluorophore-doped calcium phosphate nanoparticles for In Vivo imaging of human breast cancer. Acs Nano. 2008; 2:2075-84.http://dx.doi.org/10.1021/ nn800448r

Copyright:(c) 2012 F. Chen, et al. This is an open-access article distributed under the terms of the Creative Commons Attribution License, which permits unrestricted use, distribution, and reproduction in any medium, provided the original author and source are credited. 